Original Research Paper

\title{
Fermented Green Vegetable Soybean Meal Increases Dressed Carcass Meat and Bone Weight in Black-Boned Chickens (Fah Luang Chicken, Gallus gallus)
}

\author{
${ }^{1}$ Sukit Khantaprab, ${ }^{1}$ Buaream Maneewan, ${ }^{1}$ Tonglian Buwjoom, ${ }^{2}$ Nattakarn Khantaprab, \\ ${ }^{3}$ Kohsyo Yamauchi, ${ }^{1}$ Sontaya Niwat, ${ }^{4}$ Chamnian Yosraj and ${ }^{5}$ Koh-en Yamauchi \\ ${ }^{I}$ Faculty of Animal Science and Technology, Maejo University, Chiang Mai, Thailand \\ ${ }^{2}$ Small Animal Hospital, faculty of Veterinary, Chiangmai University, Thailand \\ ${ }^{3}$ Miyazaki Midori Pharms., Inc. 945 Hieda, Akae, Miyazaki-city 880-0912, Japan \\ ${ }^{4}$ Maejo University, Chiang Mai, Thailand \\ ${ }^{5}$ Laboratory of Animal Science, Faculty of Agriculture, Kagawa University, Miki-cho, Kagawa-ken, Japan
}

Article history

Received: 21-02-2017

Revised: 21-06-2017

Accepted: 29-08-2017

Corresponding Author:

Koh-en Yamauchi

Laboratory of Animal Science,

Faculty of Agriculture, Kagawa

University, Miki-cho, Kagawa-

ken, Japan

Fax:+87-891-3053

E-mail: yamauchi@ag.kagawa-u.ac.jp

\begin{abstract}
To use effectively waste green vegetable soyabean (edamame) and to improve the dressed carcass meat in black-boned chickens (Fah Luang chicken, Gallus gallus), fermented edamame meal was fed to blackboned chickens from 4 to 16 weeks of age. At 4 weeks of age, 20 birds (10 male and 10 female birds) were used to measure the initial weights of dressed carcass meat and each bone part. Another 60 birds were divided into 2 groups with 3 replicates of 10 chickens ( 5 male and 5 female birds) each. The control group received a basal formula diet only and the experimental group was fed $40 \mathrm{~g}$ fermented edamame meal per bird for a period of $30 \mathrm{~min}$ before being fed the basal formula diet. The weights of whole body, each dressed carcass muscle part and each bone part increased in the chickens fed fermented edamame meal $(p<0.05)$. The feed cost per $\mathrm{Kg}$ body weight gain decreased $(\mathrm{p}<0.05)$. Income over feed cost per $\mathrm{Kg}$ body weight gain, as well as income over feed cost and strain per bird, increased in the fermented edamame meal group $(p<0.05)$. These facts suggest that the feeding of fermented edamame meal to black-boned chicken induces the chicken's production due to increase of dressed carcass muscle, cheap feed cost (USD/Kg body weight gain) and high income (USD/bird), suggesting the potential for commercialization of waste edamame meal as a feed ingredient for black-boned chickens.
\end{abstract}

Keywords: Waste Edamame, Native Chicken, Meat Improvement, Feed Cost, Feeding

\section{Introduction}

Immature soybean seeds (Glycine max (L.) Merrill) harvested at an R6 immature stage (Fehr and Caviness, 1977 ) at $80 \%$ maturity (Simonne et al., 2000) are consumed as green vegetable soyabean (edamame) in almost every country. Edamame is popular as a snack and an appetizer with beer and national consumption averages 159,900 tons annually in Japan (Nguyen, 1997). Also in Thailand, a lot of edamame are exported. The processing of edamame due to increasing commodification has caused a large amount of non-standardized edamame due to small-sized and broken seeds and they are thrown away as waste edamame without being effectively used.
However, compared with agronomic soyabeans, edamame contain lower trypsin inhibitors and fewer indigestible oligosaccharides, but a greater number of vitamins (Rackis, 1978) and higher levels of phytic acids (Gupta et al., 1976). Nutritionally, edamame is rich in protein (Johnson et al., 1999; Miles et al., 2000), monounsaturated fatty acids (Johnson et al., 1999), vitamin C, vitamin E, dietary fiber (Johnson, 2002), vitamin A, calcium, isoflavones (Masuda, 1991; Rao et al., 2002), as well as calcium, phosphorus, iron, sodium, potassium, vitamin B1, vitamin B2, niacin and ascorbic acid (Miles et al., 2000). Functionally, edamame strengthen bones and teeth, lower cholesterol and prevent cardiovascular disease (Rao et al., 2002). 
Although these nutritional and functional values of edamame is well studied, few studies have been found in the literature on the effect of waste edamame on the improvement of growth performance, other than that the fermented edamame improved body weight gain and immune capacity in black-boned chickens (Buwjoom et al., 2016).

The broiler strain has been commonly bred as a poultry meat product. More recently, there has been an increased interest in healthy, low-fat and chewy poultry meats in the whole world. To produce such lower fat and uniquely textured poultry meat, Tatsuda and Fujinaka (2001) crossed the slow-growing (meat-type) native Japanese breeds and the fast-growing White Plymouth Rock (broiler) lines. Ikeobi et al. (2002) used a cross between a commercial broiler and a White Leghorn layer line because of an increasing demand for human diets that reduce fat intake (Lagarrigue et al., 2006). Although many attempts have been made to improve native chicken production by introducing exotic breeds via cross-breeding and to produce hybrids with high production performance, these improved native chickens were not accepted by some consumers, because the hybrids did not meet their expectations regarding meat quality (mainly taste). In Thailand, the quality of most Thai native chicken meat is much better than that of crossbred and broiler chickens (Kammongkun and Leotaragul, 2015) due to the lower content of fat, cholesterol and triglycerides (Pongduang et al., 2013). In particular, black-boned chickens had a high meat quality (Pripwai et al., 2014) and low content of fat and cholesterol (Jaturasitha et al., 2008; Wattanachant, 2008). As the Asian region has many kinds of indigenous chickens with meat that is lean and resilient in texture, it is better to use native chickens that have not been subjected to genetic improvement or modification to promote poultry production. In spite of the fact that many investigations on Thai indigenous chickens have involved a breeding approach based on genetic improvement, few studies involving feeding experiment to increase the quantity of each dressed carcass meat part have been examined.

In this study, to use effectively the fermented edamame, as well as to decrease the production costs associated with native chicken meat due to an increase in each dressed carcass meat part, black-boned chickens (Fah Luang chicken, Gallus gallus) were fed fermented edamame meal from 4 to 16 weeks in age and the weight of each dressed carcass muscle part and each bone part was compared with those of the control.

\section{Materials and Methods}

\section{Fermented Edamame Meal Preparation}

Among edamame, pods deemed not to have a good shape or size, as well as edamame with no seed or small seeds were treated as waste edamame in frozen food factories. The waste edamame, including seeds and pods, was cut into small pieces, dried and grinded. After weighing the raw edamame chips, the edamame chips, sugar and salt were mixed at a ratio of 100: 4: 1, respectively and this mixture was put in plastic bags for fermentation without oxygen for 7 days. The fermented edamame meal was used for up to 5 days for feeding experiments because edamame meal became bad after 5 days.

\section{Chemical Analysis}

The fermented edamame meal sample was analyzed for crude protein and crude fiber as dry matter basis, according to methods described by Buwjoom and Maneewan (2008).

\section{Birds and Housing}

A total of 80 black-boned chickens were used. At 4 weeks of age, 20 birds (10 male and 10 female) were randomly selected to be measured for the weights of dressed carcass meat, such as pectoralis major, pectoralis minor, wing muscle, thigh muscle, sartorius muscle, hindl imb muscle and whole edible muscle as well as each bone such as wing bone, thigh bone, sartorius bone, hind leg bone and total bone. The remaining 60 birds, allotted in groups according to a completely randomized block design, were divided into 2 groups with 3 replicates of 10 chickens ( 5 male and 5 female birds) each at 4 weeks of age. The control received the basal formula diet only Table 1 . The experimental group was fed $40 \mathrm{~g}$ fermented edamame meal per bird for a period of $30 \mathrm{~min}$ before being fed the basal formula diet, to reduce the total feed cost by reducing consumption of the basal formula diet. The feed intake of the experimental group was calculated from these consumptions of the basal formula diet and the fermented edamame meal. The birds had ad libitum access to feed and water from 4 to 16 weeks of age. Weekly feed intake and weight were recorded to calculate aspects of chicken production such as body growth, feed cost and income.

\section{Muscle and Bone Sampling}

At 16 weeks of age (the end of the experiment), the 10 birds per group (5 male and 5 female birds) were killed by slitting the carotid to induce blood loss, followed by removal of the visceral organs and skinning. Each skinned whole body was wrapped in a nylon bag and cooled by soaking in ice-water for more than 15 min. The whole body meats were divided into the pectoralis major, pectoralis minor, wing, thigh and sartorius. The bone and the intermuscular fat were taken out by peeling the muscles from each dressed carcass meat part. The muscle weight of each part was determined by subtracting the weight of the bone and intermuscular fat from the weight each part. Each measured value was expressed as a mean from the male and the female values. The weights of each dressed carcass meat and bone part were compared with those of the initial weights at 4 weeks of age to determine the growth of each dressed carcass meat part and each bone part. 
Table 1. Feed composition of formula diet $(0-8$ and 9-16 weeks of age)

\begin{tabular}{lcr}
\hline Ingredients (kg) & $0-8 \mathrm{~W}$ & $9-16 \mathrm{~W}$ \\
\hline Corn & 55.00 & 41.50 \\
Soybean meal & 23.17 & 7.65 \\
Rice bran & 21.08 & 49.58 \\
Salt & 0.25 & 0.25 \\
Dicalcium phosphate & - & 0.52 \\
Premix & 0.50 & 0.50 \\
Total & 100.00 & 100.00 \\
Cost (bath) & 10.97 & 10.20 \\
Calculated nutrient & & \\
composition(\% air dry) & & \\
Protein & 19.00 & 14.50 \\
ME (KcalME/kg) & $2,800.00$ & $2,600.00$ \\
Fiber & 5.34 & 6.22 \\
Fat & 6.93 & 11.64 \\
Calcium & 0.09 & 0.18 \\
Phosphorus, available & 0.32 & 0.49 \\
Methionine & 0.28 & 0.15 \\
Lysine & 1.2 & 0.63 \\
\hline Prem contains 2.20 million
\end{tabular}

Premix contains 2.20 million units Vitamins A; 0.45 million units vitamin D3; $2.50 \mathrm{~g}$ vitamin $\mathrm{E}$; $0.40 \mathrm{~g}$ vitamin $\mathrm{K} 3 ; 0.20$ mg vitamin $\mathrm{B} 1 ; 0.90 \mathrm{~g}$ vitamin $\mathrm{B} 2 ; 0.30 \mathrm{~g}$ Vitamin $\mathrm{B} 6 ; 0.004$ $\mathrm{g}$ vitamin $\mathrm{B} 12 ; 1.10 \mathrm{~g}$ pantothenic acid; $4.00 \mathrm{~g}$ Nicotinic acid; $0.060 \mathrm{~g}$ folic acid; $0.040 \mathrm{~g}$ biotin; $8.00 \mathrm{~g} \mathrm{Fe} ; 1.60 \mathrm{~g}$ copper, $14.00 \mathrm{~g}$ manganese; 8.00 grams zinc; $0.12 \mathrm{~g}$ iodine, $0.032 \mathrm{~g}$ selenium; $060 \mathrm{~g}$ cobalt; $0.036 \mathrm{~g}$ potassium; $162.20 \mathrm{~g}$ choline chloride; add feed media until $1.00 \mathrm{~kg}$

\section{Statistical Analysis}

Growth performance, feed cost and income between the control and the experimental groups were also calculated from these 3 replicates. The results were evaluated using SPSS (a statistical analysis software program). Statistical differences among treatments were separated using the F-test at 5\% significance level.

All experimental and animal management procedures were performed according to the Ethics, Principles and Guidelines for the Use of Animals for Scientific Purposes, National Research Council of Thailand.

\section{Results}

The chemical composition of fermented edamame meal is as follows: The content of crude protein and crude fiber as dry matter basis were 23.00 and $16.03 \%$, respectively.

Table 2 shows the initial weights of fresh body, pectoralis major, pectoralis minor, wing muscle, thigh muscle, sartoriususcle, hind limb muscle, whole edible muscle, wing bone, thigh bone, sartorius bone, hind leg bone and total bone in the 4-week-old black bone chickens before starting the feeding experiment using fermented edamame meal. Compared with the control at the end of the feeding period (at 16 weeks of age), the final fresh body weight, as well as all values of each dressed carcass muscle part and each bone part increased in the chickens fed fermented edamame meal $(p<0.05)$ Table 3 .
Table 2. Initial weights of fresh body, each dressed carcass meat and bonepart $(\mathrm{g})$ in the black bone chickens (Fah Luang chicken)at 4 weeks of age (Mean \pm SEM, $n=20)$

\begin{tabular}{ll}
\hline Item & Initial weight $(\mathrm{g})$ \\
\hline Initial body weight & $153.07 \pm 15.53$ \\
Pectoralis major & $7.06 \pm 0.82$ \\
Pectoralis minor & $2.48 \pm 0.16$ \\
Wing muscle & $4.31 \pm 0.26$ \\
Thigh muscle & $8.13 \pm 0.53$ \\
Sartorius muscle & $7.01 \pm 0.35$ \\
Hind leg muscle & $15.15 \pm 0.88$ \\
Whole edible muscle & $28.99 \pm 1.64$ \\
Wing bone & $5.27 \pm 0.48$ \\
Thigh bone & $2.6 \pm 0.21$ \\
Sartorius bone & $3.5 \pm 0.60$ \\
Hind legs bone & $6.10 \pm 0.80$ \\
Total bone & $11.36 \pm 1.36$ \\
\hline
\end{tabular}

Table 3. Final weights of fresh body, each dressed carcass meat and bone part $(\mathrm{g})$ in the control and black bone chickens (Fah Luang chicken) fed fermented green vegetable soybean mealat 16 weeks of age (Mean \pm SEM, $\mathrm{n}=10$ )

\begin{tabular}{llll}
\hline & Treatment & & \\
\cline { 2 - 4 } Item & Control & Fermented feed & P-value \\
\hline Final body weight & $937.73 \pm 46.24^{\mathrm{b}}$ & $1113.59 \pm 96.3^{\mathrm{a}}$ & 0.0109 \\
Pectoralis major & $75.84 \pm 6.76^{\mathrm{b}}$ & $91.62 \pm 6.68^{\mathrm{a}}$ & 0.0104 \\
Pectoralis minor & $30.78 \pm 2.78^{\mathrm{b}}$ & $37.33 \pm 2.80^{\mathrm{a}}$ & 0.0104 \\
Wing muscle & $72.00 \pm 5.73^{\mathrm{b}}$ & $81.25 \pm 4.34^{\mathrm{a}}$ & 0.0317 \\
Thigh muscle & $100.43 \pm 8.19^{\mathrm{b}}$ & $127.30 \pm 13.94^{\mathrm{a}}$ & 0.0104 \\
Sartorius muscle & $75.80 \pm 5.14^{\mathrm{b}}$ & $96.37 \pm 9.72^{\mathrm{a}}$ & 0.0059 \\
Hind legs muscle & $176.23 \pm 12.53^{\mathrm{b}}$ & $223.67 \pm 23.53^{\mathrm{a}}$ & 0.0075 \\
Whole edible muscle & $354.85 \pm 24.62^{\mathrm{b}}$ & $433.88 \pm 33.42^{\mathrm{a}}$ & 0.0054 \\
Wing bone & $23.51 \pm 2.88^{\mathrm{b}}$ & $29.21 \pm 3.94^{\mathrm{a}}$ & 0.0462 \\
Thigh bone & $14.22 \pm 14.22^{\mathrm{b}}$ & $18.19 \pm 1.62^{\mathrm{a}}$ & 0.0044 \\
Sartorius bone & $19.17 \pm 1.74^{\mathrm{b}}$ & $23.61 \pm 1.42^{\mathrm{a}}$ & 0.0045 \\
Hind legs bone & $33.40 \pm 2.87^{\mathrm{b}}$ & $41.80 \pm 2.79^{\mathrm{a}}$ & 0.0033 \\
Total bone & $56.91 \pm 5.23^{\mathrm{b}}$ & $71.01 \pm 6.15^{\mathrm{a}}$ & 0.0082 \\
\hline a,b Means followed by different letters are significantly different \\
(p<0.05) & & &
\end{tabular}

Also in regard to the daily weight gain of the fresh body, each dressed carcass muscle part and each bone part during 4 to 16 weeks of age increased in the chickens fed fermented edamame meal $(p<0.05)$ Table 4. The black bone chickens fed fermented edamame meal showed no change in feed intake (but for a low value), but they increased in body weight gain, resulting in improved feed efficiency $(p<0.05)$ Table 5. Feed cost per bird, as well as cost of feed and strain per bird, did not differ between the control and the experimental groups, but the feed cost per $\mathrm{Kg}$ body weight gain decreased $(p<0.05)$. Income over feed cost per Kg body weight gain, as well as income over feed cost and strain per bird, increased in the fermented edamame meal group $(\mathrm{p}<0.05)$. 
Table 4. Weight gain (g) per day of fresh body, each dressed carcass meat and bone part in the control and black bone chickens (Fah Luang chicken) fed fermented green vegetable soybean meal at 16 weeks of age (Mean \pm SEM, $n=10$ )

\begin{tabular}{|c|c|c|c|}
\hline \multirow[b]{2}{*}{ Item } & \multicolumn{3}{|l|}{ Treatment } \\
\hline & Control & Fermented feed & $\mathrm{P}$-value \\
\hline Whole body growth & $9.34 \pm 0.64^{b}$ & $11.44 \pm 1.07^{\mathrm{a}}$ & 0.0098 \\
\hline Pectoralis major & $0.82 \pm 0.08^{\mathrm{b}}$ & $1.01 \pm 0.07^{\mathrm{a}}$ & 0.0097 \\
\hline Pectoralis minor & $0.34 \pm 0.03^{\mathrm{b}}$ & $0.41 \pm 0.03^{\mathrm{a}}$ & 0.0113 \\
\hline Wing muscle & $0.81 \pm 0.07^{\mathrm{b}}$ & $0.92 \pm 0.05^{\mathrm{a}}$ & 0.0330 \\
\hline Thigh muscle & $1.10 \pm 0.10^{\mathrm{b}}$ & $1.42 \pm 0.16^{\mathrm{a}}$ & 0.0105 \\
\hline Sartorius muscle & $0.82 \pm 0.06^{\mathrm{b}}$ & $1.06 \pm 0.12^{\mathrm{a}}$ & 0.0061 \\
\hline Hind legs muscle & $1.92 \pm 0.16^{\mathrm{b}}$ & $2.48 \pm 0.28^{\mathrm{a}}$ & 0.0077 \\
\hline Whole edible muscle & $3.88 \pm 0.31^{\mathrm{b}}$ & $4.82 \pm 0.39^{\mathrm{a}}$ & 0.0053 \\
\hline Wing bone & $0.22 \pm 0.03^{\mathrm{b}}$ & $0.29 \pm 0.05^{\mathrm{a}}$ & 0.0435 \\
\hline Thigh bone & $0.14 \pm 0.01^{\mathrm{b}}$ & $0.19 \pm 0.02^{\mathrm{a}}$ & 0.0054 \\
\hline Sartorius bone & $0.19 \pm 0.02^{b}$ & $0.24 \pm 0.02^{\mathrm{a}}$ & 0.0067 \\
\hline Hind legs bone & $0.32 \pm 0.03^{\mathrm{b}}$ & $0.43 \pm 0.04^{\mathrm{a}}$ & 0.0044 \\
\hline Total bone & $0.54 \pm 0.06^{\mathrm{b}}$ & $0.71 \pm 0.08^{\mathrm{a}}$ & 0.0088 \\
\hline
\end{tabular}

$\overline{{ }^{a, b} \text { Means followed by different letters are significantly different }(\mathrm{p}<0.05)}$

Table 5. Growth performance, feed cost and income in the control and black bone chickens (Fah Luang chicken) fed fermented green vegetable soybean meal at 16 weeks of age (Mean \pm SEM, $n=3$ )

\begin{tabular}{llll}
\hline & Treatment & \\
Item & -------1 & Fermented feed & P-value \\
\hline Feed intake (W4-16) (g/bird) & Control & $4,406.97 \pm 232.76$ & 0.1700 \\
Body weight gain (W4-16) (g/bird) & $787.95 \pm 39.15^{\mathrm{a}}$ & $957.22 \pm 39.13^{\mathrm{b}}$ & 0.0100 \\
Feed efficiency (W4-16) (\%) & $17.88 \pm 0.06^{\mathrm{a}}$ & $23.62 \pm 0.14^{\mathrm{b}}$ & 0.0000 \\
Feed cost (USD /bird) & $1.30 \pm 0.04$ & $1.35 \pm 0.05$ & 0.0960 \\
Feed cost (USD/ Kg body weight gain) & $1.66 \pm 0.05^{\mathrm{a}}$ & $1.41 \pm 0.03^{\mathrm{b}}$ & 0.0038 \\
Cost of feed and strain (USD/bird) & $2.73 \pm 0.04$ & $2.78 \pm 0.05$ & 0.9600 \\
Income over feed cost & $2.06 \pm 0.05^{\mathrm{b}}$ & $2.30 \pm 0.03^{\mathrm{a}}$ & 0.0038 \\
(USD/ Kg body weight gain) & & & 0.0050 \\
Income over feed cost and strain (USD/bird) & $0.75 \pm 0.08^{\mathrm{b}}$ & $1.36 \pm 0.09^{\mathrm{a}}$ & 0.000 \\
\hline
\end{tabular}

$\overline{\mathrm{a}, \mathrm{b}}$ Means followed by different letters are significantly different $(\mathrm{p}<0.05)$

\section{Discussion}

Although soyabean meal is the most commonly used protein source in poultry diets, soyabean prices have reached the highest values in years, researchers have proposed alternatives for poultry diets such as Nigella sativameal (Abd El-Hack et al., 2016). However, we have tried to develop locally produced waste feed ingredients to reduce production costs. Most of the edamame produced in Thailand has been exported to Japan as a snack. During the steps involved in processing edamame, around 3,000 to 4,000 tons per year are wasted as a by-product from one frozen food factory in the Chiangmai area and the wasted edamame used as fertilizer and dairy cow feed.

On the other hand, now global food culture has been changing from high calorie foods like a broiler meat to light foods like native lean chicken meat. In line with this demand, many genetic improvements in broiler chicken cross-breeding using lean chickens have been conducted. In Thailand, lean type indigenous chickens traditionally have been bred. However, as Thai consumers prefer low fat and antibiotic-free white meat (Wattanachant, 2008), a
Thai indigenous chicken, especially the black-bone chicken, is a higher price to buy, approximately two or three times higher than that of commercial broilers (Chotsangkad and Kongrattananun, 1999).

In this study, compared with the control, the body weight gain increased in the edamame group at 16 weeks of age. This increased body weight corresponds with results described in black-bone chickens fed fermented edamame meal (Buwjoom et al., 2016). The present increase in body weight gain is induced by an increase in each dressed carcass muscle part and each bone part. Although the bone weight increase does not contribute to meat production, the increased bone weight means strong bones. Such a phenomenon suggests the possibility that feeding fermented edamame meal to hens might strengthen the eggshell, because edamame strengthens bones and teeth (Rao et al., 2002). As country roads in the some Asian regions are unpaved, some eggs are broken during transportation. Therefore, eggs strengthened by edamame may contribute to the egg industry as being the hardest to break during transportation. On the other hand, in regard to poultry 
production, the present increase in each dressed carcass muscle part is the most valuable result. In the case of heavy-type chickens such as broiler chickens, an improvement in growth performance is comparatively difficult, because weight gain has been maximized by gene improvement. On the contrary, in the case of the present lean-type chicken, the weight gain seems to be easily elevated even by $22.02 \%$ crude protein in fermented edamame meal, because lean chickens are more prone to protein efficiency than fat chickens (Leclercq and Guy, 1991). In addition, the fermentation of feed elevated the concentration of lactic acid (Engberg et al., 2006; Heres et al., 2003a) and the numbers of lactic acid bacteria (Winsen et al., 2001; Heres et al., 2003a), reducing Salmonella enteritidis. Fermented liquid feed could reduce the transmission of Salmonella in chicken flocks (Heres et al., 2003b) and fermented feeds and fermentable carbohydrates improved the gut environment in nonruminants (Niba et al., 2009). These literatures suggest that the present fermented edamame meal resulted in increased meat weight due to its improving the gut environment by fermentation. To reduce the cost of wage and increase the benefits, Pukkalanun and Pattanachatchai (2015) recommend that the chicken farmers should promote the native chicken's potential and that the rearing period should be less than 7 months. However, in this study, production costs were lowered only by feeding fermented edamame meal. The present feed efficiency during 4 to 16 weeks of age was improved because the feed intake was not changed (low value), but body weight gain increased in the fermented edamame meal group. Feed cost (USD/bird), as well as the cost of feed and strain (USD/bird) were not different between the control and experimental groups, but feed cost (USD/Kg body weight gain) was cheaper in the experimental group, resulting in an increased income over feed cost (USD/Kg body weight gain) and increased income over feed cost and strain (USD/bird). This result suggests that the fermented edamame meal has a commercialization value in fermented waste edamame.

\section{Conclusion}

In conclusion, the feeding of fermented edamame meal to black-boned chickens could increase each dressed carcass meat part and each bone part of the birds, lower chicken production costs and raise the profits of poultry farmers. These facts suggest that the feeding of fermented edamame meal induces the chicken's production due to increase of dressed carcass muscle, cheap feed cost (USD/Kg body weight gain) and high income (USD/bird), suggesting the potential for commercialization of waste edamame meal as a feed ingredient for black-boned chickens.

\section{Author's Contributions}

Sukit Khantaprab and Nattakarn Khantaprab, Kohsyo Yamauchi, Sontaya Niwat and Chamnian Yosraj: Conception and design and/or acquisition of data and/or analysis and interpretation of data.

Buaream Maneewan and Tonglian Buwjoom: Drafting the article or reviewing it critically for significant intellectual content.

Koh-en Yamauchi: Final approval of the version to be submitted and any revised version.

\section{Declaration Interest}

The authors state no conflict of interest and are responsible for the content and writing of this article.

\section{References}

Abd El-Hack, M.E., M. Alagawany, M. Saeed, M. Arif, M.A. Arain and Z.A. Bhutto et al., 2016. Effect of gradual substitution of soyabean meal by Nigella sativa meal on growth performance, carcass traits and blood lipid profile of growing Japanese quail. J. Anim. Feed Sci., 25: 244-249.

Buwjoom, T. and B. Maneewan, 2008. The survey on sources and quantities of agriculture waste/by-product in Sansai, Doi Saket, Mae Rim and Mae Taeng Districts, Chiang Mai Province for its prospective use as raw material in animal feed composition. Proc. Conf. Maejo University Annu. Thailand.

Buwjoom, T., B. Maneewan and K. Yamauchi, 2016. The using of fermented vegetable soybean waste and banana stem in Black-bone chicken diets. Proceedings of the 17th Asian-Australasian Association of Animal Production Societies Animal Science Congress, Aug. 22-25, Fukuoka, Japan, pp: 1689-1692.

Chotsangkad, R. and N. Kongrattananun, 1999. Growth and carcass quality of native chickens raised under the natural day, length and the photoperiod of twenty three hours a day. The Kasetsart J., 33: 60-74.

Engberg, R.M., M.S. Abousekken, M. Hammershj and B.B. Jensen, 2006. Fermented feed for organic layers. World's Poultry Sci. J.

Fehr, W.R. and C.E. Caviness, 1977. Stage of soybean development. 1st Edn., Iowa Cooperative Extension Service, Des Moines, pp: 11.

Gupta, A.K., M. Kapoor and A.D. Deodhar, 1976. Chemical composition and cooking characteristics of vegetable and grain-type soybeans. J. Food Sci. Technol., 13: 133-137.

Heres, L., B. Engel, F. van Knapen, M.C. de Jong and J.A. Wagenaar et al., 2003a. Fermented liquid feed reduces susceptibility of broiler for salmonella enteritidis. Poult. Sci., 82: 603-611. 
Heres, L., H.A.P. Urlings, J.A. Wagenaar and M.C. de Jong, 2003b. Transmission of salmonella between broiler chickens fed with fermented liquid feed. Epidemiol. Infect., 132: 107-116. DOI: $10.1017 / \mathrm{S} 0950268803001213$

Ikeobi, C.O.N., J. Woolliams, D.R. Morrice, A. Law and D. Windsor et al., 2002. Quantitative trait loci affecting fatness in the chicken. Anim. Genet., 33: 428-435.

Jaturasitha, S., T. Srikanchai, M. Kreuzer and M. Wicke, 2008. Differences in carcass and meat characteristics between chicken indigenous to northern Thailand (Black-Boned and Thai Native) and imported extensive breeds (Bresse and Rhode Island Red). Poult. Sci., 87: 160-169. DOI: 10.3382/ps.2006-00398

Johnson, D., 2002. Edamame. Eng. Technol. Sustainable World. 7: 11-12.

Johnson, D., S. Wang and A. Suzuki, 1999. Edamame: A Vegetable Soybean for Colorado. In: Perspectives on New Crops and New Use, Janick, J. (Ed.), ASHS Press. Alexandria, Va. pp: 385-587.

Kammongkun, J. and A. Leotaragul, 2015. Estimation of genetic parameters for economic traits in Thai native chicken (Pradu-Hangdum Chiangmai) for fourteen generations of selection. Hon Kaen Agr. J., 43: 196-199.

Lagarrigue, S., F. Pitel, W. Carre, B. Abasht and P.L. Roy et al., 2006. Mapping quantitative trait loci affecting fatness and breast muscle weight in meattype chicken lines divergently selected on abdominal fatness. Genet. Sel. Evol., 38: 85-97. DOI: $10.1051 /$ gse:2005028

Leclercq, B. and G. Guy, 1991. Further investigations on protein requirement of genetically lean and fat chickens, Br. Poult. Sci., 32: 789-798.

Masuda, R., 1991. Qualityand improvement of vegetable soybean. In: Vegetable Soybean: Research Needs for Production and Quality Improvement, Shanmugasundaram, S. (Ed.), The Center, Taiwan, pp: 92-102.

Miles, C.A., T.A. Lumpkin and L. Zenz, 2000. Edamame. Washington State University Cooperative Extension Bull.

Nguyen, V.Q., 1997. Edamame (vegetable green soybean).
Niba, A.T., J.D. Beal, A.C. Kudi and P.H. Brooks, 2009. Bacterial fermentation in the gastrointestinal tract of non-ruminants: Influence of fermented feeds and fermentable carbohydrates. Trop. Anim. Health Prod., 41: 1393-1407. DOI: 10.1007/s11250-009-9327-6

Pukkalanun, N. and N. Pattanachatchai, 2015. Cost/benefit analysis of native chicken rearing in surin province, Thailand. Khon Kaen Agr. J., 43: 231-233.

Pripwai, N., W. Pattanawong, M. Punyatong and T. Teltathum, 2014. Carcass characteristics and meat quality of Thai inheritance chickens. J. Agri. Sci., 6: 182-188.

Pongduang, U., A. Leotaragul, A. Pianmongkol, P. Thakeow and S. Jaturasitha, 2013. Eating quality and flavor of Pradu Hang Dam Chiang Mai 1, Pradu Hang Dum's crossbred and broiler. J. Agr. Res. Ext., 30: 37-46.

Rackis. J.J., 1978. Biochemical Changes in Soybeans: Maturation, Post-Harvest Storage and Processing and Germination. In: Post-Harvest Biology and Technology, Hultin, H.O. and M. Milner, (Eds.), Food and Nutrition Press, Westport, Conn, pp: 34-76.

Rao, M.S.S., A.S. Bhagsari and A.I. Mohamed, 2002. Fresh green seed yield and seed nutritional traits of vegetable soybean genotypes. Crop Sci., 42: 1950-1958.

Simonne, A.H., M. Smith, D.B Weaver, T. Vail and S. Barnes et al., 2000. Retention and changes of soy isoflavones and carotenoids in immature soybean seeds (Edamame) during processing. J. Agric. Food Chem., 48: 6061-6069. DOI: 10.1021/jf000247f

Tatsuda, K. and K. Fujinaka, 2001. Genetic mapping of the QTL affecting abdominal fat deposition in chickens. J. Poult. Sci., 38: 266-274.

Wattanachant, S., 2008. Factors affecting the quality characteristics of Thai indigenous chicken meat. Suranaree J. Sci. Technol., 15: 317-322.

Winsen, R.L.V., B.A.P. Urlings, L.J.A. Lipman, J.M.A. Snijders and D. Keuzenkamp et al., 2001. Effect of fermented feed on the microbial population of the gastrointestinal tracts of pigs. Applied Environ. Microbiol., 67: 3071-3076. 